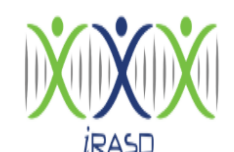

iRASD
Pakistan Journal of Humanities and Social Sciences

Volume 9, Number 3, 2021, Pages 495-504

Journal Homepage:

https://journals.internationalrasd.org/index.php/pjhss
PAKISTAN JOURNAL OF

HUMANITIES AND SOCIAL

SCIENCES (PJHSS)

\title{
Quality Education and Educational Facilities in Secondary Schools: A Nexus
}

\author{
Muhammad Latif Javed ${ }^{1}$, Barirah Ishaq ${ }^{2}$, Muhammad Nadeem Javed ${ }^{3}$ \\ ${ }^{1}$ Assistant Professor, The Islamia University of Bahawalpur, Pakistan. Bahawalnagar Campus \\ Email: latif.javed@iub.edu.pk \\ ${ }^{2}$ Visiting Lecturer, The Islamia University of Bahawalpur, Pakistan. Bahawalnagar Campus \\ Email: barirahishaq@gmail.com \\ ${ }^{3}$ Visiting Lecturer, Mirpur University of Science \& Technology Azad Jammu \& Kashmir (AJ\&K) \\ Email: nadeemjaved05@gmail.com
}

\section{ARTICLE INFO}

Article History:

Received: November 10, 2021

Revised: December 25, 2021

Accepted: December 27, 2021

Available Online: December 28, 2021

\section{Keywords:}

Educational Facilities

Physical Infrastructure

Teaching- Learning Material

Library

Science and Computer Laboratory

\section{ABSTRACT}

This study examines the educational facilities which are important in providing quality education at secondary schools. The researcher examined the appropriateness of physical infrastructure, teaching-learning material, library, computer laboratory, and science laboratory at secondary schools to find out nexus of quality education with these provided educational facilities. The research design of the study was quantitative in nature. The research population included 194 secondary schools in Bahawalnagar, 194 head teachers, and 3739 SSTs. The sample of the study was comprised of over 45 head teachers and 90 sets of all the secondary schools of Tehsil Bahawalnagar selected by using cluster random sampling technique. A questionnaire was developed on a 5- point Likert scale to examine \& analyze the educational facilities including teachinglearning material, computer laboratory, and library and science laboratory. An observation checklist was also developed and used for the collection of data. The further checklist was divided into three options yes, no and status further divided into two options useable and unusable, appropriateness, and inappropriateness. Data was collected \& analyzed using descriptive statistics including percentage and frequency to examine the appropriateness of educational facilities. Quantitative data was analyzed using computer-generated software SPSS. Results revealed that the majority of the respondents were agreed with educational facilities. The study concludes that the researcher observe the educational facilities through a checklist maximum facilities were present, useable and appropriateness of these was also registered. Research study recommended that more opportunities for students may be available for experience science being exposed to more practical's work in labs which may enhance better performance in science subjects.

(c) 2021 The Authors, Published by iRASD. This is an Open Access Article under the Creative Common Attribution Non-Commercial 4.0

Corresponding Author's Email: latif.javed@iub.edu.pk

\section{Introduction}

Education has main importance with the development of nations. The nations' history is replete with changes and revolutions with in the field of education. The school organizations became the sign of changes and revolutions with in the industrialized world. The Government of Pakistan time to time tried its best to make sure the needs and aspirations of individuals as also as society. During this view, more than a few steps are taken to make sure that both material and human resources are place jointly to get the right settlement of education.

In the modern age, the schools became axis of innovation. Physical facilities included in the school are; school building, classrooms, library, laboratories, toilet facilities, office and 
alternative materials and infrastructures that encourage the students in the direction of learning. According to (Young, Green, Roehrich-Patrick, Joseph, \& Gibson, 2003) school of modern age has become the model of easiness. Sufficient physical facilities are being provided to impart quality education. Encouraging learning environment is merged of physical facilities provided to schools. Moreover, physical facilities are the essential things which lead students towards their destination.

The existence of the building of the school doesn't indicate teaching and learning but there's the use of substantial resources. School is formed for purpose of teaching and learning. It's quite and clear that learning doesn't conceivable by confining someone into four walls but it only possible through the interaction with internal and external environment. Student cannot get education only in classroom and that we also cannot build them by into the four walls (Vandiver, 2011).

School facilities ought to be used for various purposes; it shouldn't solely be specified for students but it must be obtainable for community use after the school time. These amenities must be used for the development of education in addition to for students. The standard of product takes a direct association with the traits of the facilities positional within the method of invention. Through applicable programming facilities for various function is also accessible to the community throughout school. In several countries, low level of education is because of inadequate level of physical facilities. Physical facilities provide students such form of atmosphere wherever they'll struggle whole-heartedly. (Shami \& Hussain, 2005) describe that the chance of physical easiness has an important effect on students functioning.

A school library do not valuable if books aren't sufficient and modern as its impact could solely be there significant if library might be opened to the student forever substantial duration of your era during a school day. By means of all on top of mention reality, it's unhappy recognize several schools operate while not libraries had previous noted that whole nonappearance of Associate in Nursing prearranged school's library would still spell dooms for thousands of secondary school students. This declaration obviously explains that several schools function while not libraries and had affects educational presentation of students (Davis, 2015).

Moreover, library of schools as associates in instructional resource which can be considerably motivate students' accomplishment when dominant for pupils' relatives background. This finds the impact of size of library and their activities are optimistic in fifteen out of eighteen analysis. There are connection between academic performances and instructional facilities. Library associate with intellectual accomplishment and school faculties with good operational library usually sustain high educational performance (Tutkun, 2011).

Educational facilities are important in providing quality education at secondary schools. The researcher found it utmost important to measure the available educational facilities at secondary schools in district Bahawalnagar. These looks to be insufficient provision of this facilities, some of the existing ones seems to be in a falling down state, while some seems lack good maintenance or may not function at all. Teaching- learning material and library was the most observable workings of government educational condition and their deficiency is often prominent by observer. This study was also aiming to examine the appropriateness of science and computer laboratory in secondary schools. The Objectives of the Study are to examine the educational facilities at secondary level and to analyze the appropriateness of teachinglearning material in secondary schools. The Research Questions are given below;

- What is the availability of physical infrastructure in secondary schools?

- Does the boundary wall of school build appropriate?

- Are classrooms and furniture present for students?

- What is the appropriateness of teaching-learning material in secondary schools?

- Are academic facilities present in secondary schools?

- Are audio visual aids being used in classrooms?

The aim of research was to analyze educational facilities at secondary schools in district Bahawalnagar. The essence of any research endeavor was an addition to the educational 
facilities satisfaction, to find solution to the numerous problems confronting the context of the society. It is therefore hoped that the study will consequently contribute in the existing literature on availability of attractive and appropriate physical infrastructure in secondary schools. Teaching-learning materials stimulate critical and creative thinking in learners which is an important to examine the appropriateness of teaching-learning material and library in secondary schools. The purpose of this research is to help the learner to develop the skill of analytical enquiry, motivate to produce their own potential through educational facilities.

\section{Literature Review}

This part of research study is to review the related literature to discuss its background, status and future implications in the system of education at secondary level. The literature was reviewed from books, research thesis, articles and research work published in different journals at national and international level.

\subsection{Educational Facilities in Secondary Schools}

Educational facilities are available for pupils, each chance to create prospective factor. Educational facilities include buildings, and necessary equipment for useful or well-organized function of public education program, libraries, classroom, building equipment, fine arts room, restrooms, media centers, specialized laboratories, cafeterias, fixtures connected external facilities, paving, landscaping, and comparable article which the State Board of Education might conclude compulsory.

Educational facilities constitute main influential factor toward make sure quality education. It is one of the standards for measuring the level of educational development and growth. It implies substantial cost of the school system for their establishment, if not appropriately maintained and managed; it will have an effect on the academic performance of students. School facility is the process of make certain that buildings and other technological systems hold the operations of an organization (Asaolu, 2003).

\subsection{Student /Teacher Ratio}

School Education Department (2018) endorsed that one teacher for forty students in the classroom if the class consists of many students, then it is divided in two or more groups. The number of every room must be available in the school. Usually, every group of the class must have a separate room. So extra rooms should be available for coming day requires. Furthermore, there are few subjects e.g. science subjects etc. which cannot be trained in the conventional classroom. There are separate rooms must be available for science practical subjects. It is necessary teaching learning process presents in a good way, curriculum manage for learner's achievement than reflecting outcomes of schooling.

\subsection{School building in Secondary School}

Physical conditions of schools have directly positive and negative effects on teacher spirits, personal safety of teachers, usefulness condition in the classroom, and also effect on general learning assessment. Renovation of school building because teachers feel satisfy, pleasant, develop a hope, built belief that school take step for development. If authorities do not focus on decaying buildings and do not try to established building in district then school atmosphere has badly affected more frustration and despair, teachers reporting about every damaging aspects of schools burned out lights, leaking roofs, and broken toilets were the typical conditions in the schools (Schneider, 2002).

\subsection{Classrooms and Furniture}

Indoor and outdoor both environments are valuable and convince children to learn through different activities. Researcher explained that Indoor and outdoor space may not only be different according to location, situation and climate, but research has agenda for developing schools. Furthermore, it is essential point that furniture in the classroom ought to be movable, comfortable, attractive, durable, storable and according to child-sized. Particularly it is necessary for students that class chairs or benches it should be light and easily handle, and chair's backs 22 inches high. There are different Chairs in different sizes, chair size completely based on classrooms size and student's age. It has important that clock size should be big because every student easily to see clock. Display frame and book shelves must to movable and easily reachable to pupils and teachers (Bruce, 2006). 


\subsection{Availability and Effects of Teaching and Learning Materials on Secondary School}

According to Weems and Rogers (2015) the goal of classroom observations is to obtain a representative sample of a teacher's performance in the classroom. Examination has been undertaking student learning assessments for secondary level. Punjab is the first province to launch a large-scale assessment program. In a study combining 2009 data on school characteristics with examination scores Andrabi et al. (2016) attempt to link student performance to school inputs. The authors find variations at the school level to be important in explaining differences in student achievement: "The gap between good and bad district is relatively smaller compared to the gap between good and bad schools within any given district." Factors associated with better student performance are lower student-teacher ratios, better-educated and more experienced teachers, and better school facilities such as blackboards. Moreover, districts with higher enrollments do not necessarily have better child learning results. Regarding quality education, Khan (2018) also conducted a study aimed at finding the instructional contribution of government and community schools who suggested that, in the hierarchy of every institution the heads were responsible to achieve quality education by making their concerned institutions effective.

Due to its importance in education, it is considered the 3rd pillar in Punjab Education Sector Reforms Programs. Improving the quality of education is not easy but a challenging task (Perera, 2014). Quality is a broader concept. So, it is needed to classify it in further elements. The important variables of quality of education are (a) facilities of education in schools like playground, building, toilets, clean water, electricity, boundary wall and overall cleanliness (b) effective school council (c) proper availability and utilization of funds (d) general administration of head of institution and (e) annual results.

Facilities of education play an important role in promotion of education. According to UNESCO every school must has proper building, proper classrooms, science laboratories, and library, playground, clean drinking water, toilets for students and teachers, boundary wall, and link with road. But situation in Pakistan is totally different. These facilities motivate students to learn as well as teachers to teach. Besides this, these facilities have also positive impact on parents. Hence, they send their children to school to learn. In this way, the education of the country improved. The possible reasons of lack of facilities were as under:

- Less consumption on education is major reason of lack of facilities. As it is well known that Pakistan consumes less than $2 \%$ of Gross Domestic Product (GDP). According to World Bank (2007) Pakistan is only country on the globe which consume less than $2 \%$ of her GDP other than Afghanistan.

- Lack of commitment by the government was another reason of poor facilities in schools. According to New Education Policy 2009, the educational targets were not chased due to commitment gap of the past government (Government of Pakistan, 2009).

- Lack of monitoring was another reason of not provision of missing facilities in school. The latest educational policy of Pakistan 2009 proofs it that implementation gap becomes the reason of poor performance of education (Government of Pakistan, 2009). It can be said that it is due to poor monitoring mechanism that educational targets cannot be chased in past.

The government of Punjab is taking step to improve the quality of education by providing missing facilities to schools. According to World Bank Report (2007) the Punjab government is trying to improve education under Punjab Education Sector Reforms Programs. Provision of missing facilities is one of the areas of improving quality of education.

To check the educational facilities is done by principal at the school level or the head teacher in secondary school. Monitoring is a means by which information is gathered while evaluation is the judgment on the effectiveness of action taken based on the impact on the quality of children's learning. In schools which have a large population there are heads of departments and heads of subjects who also have a role in monitoring and evaluation of the teaching and learning process. They report their findings every fortnight. There are various activities that are monitored and evaluated in the day to day teaching and learning process. These include, teacher's preparation documents the physical attendance of classes by teachers 
and students, students and teachers reporting time. The learner's reaction is also used to determine if the students enjoyed the lesson therefore, leading to conclusion as to whether learning has taken place or not. (Emily Beatrice, 2015).

\section{Methodology}

In this part methodology of the research is explained. The objective of this research was to analyze the educational facilities in secondary schools of district Bahawalnagar. This chapter explained research design, target population, sampling techniques, research instruments, data collection and data analysis technique.

\subsection{Nature Design of the research}

The survey type design of the quantitative research was used. The sample of the study was selected using cluster random sampling technique. Cluster is location within which an intact group of members of population can be found in district.

This is the descriptive type of study in which survey method was used to collect data along with observation checklist to compare and analyze the presence, availability and appropriateness of physical facilities. This research was conducted to explore an analysis of educational facilities in secondary schools of district Bahawalnagar. The study was based on cluster random sampling technique. Quantitative method was used in this research.

\subsection{Population of the study}

All head teachers and secondary school teachers (SSTs) (male, female) working in secondary schools of Bahawalnagar district was constitute the population of the study. Population size was comprised of 194 head teachers and 3739 SSTs in secondary schools of district Bahawalnagar. There are five tehsils Bahawalnagar, Haroonabad, Chistian, Fortabbas and Minchanabad in district Bahawalnagar.

\subsection{Sample of the study}

The sample of research was comprised of all head teachers and secondary school teachers of 45 secondary schools in Tehsil Bahawalnagar selected by using cluster random sampling technique.

\subsection{Instrument of the study}

Research instrument attained the most important position in this entire study. As the research, was quantitative, questionnaire based on closed ended statements and observation checklist was developed and used for the collection of data. The questionnaire was developed on a 5- point Likert Scale (from strongly agree to strongly disagree). Following are some major topics about educational facilities at school level were asked from head teachers and SSTs. List of some major topics:

1. Availability of educational facilities.

2. Use of educational facilities.

3. Quality of educational facilities.

Observation checklist was based on structured observation list. Observation checklist was included items that were relevant to the research objectives and research questions of the study, which are appropriate for the research. Observation checklist was consisted on three options yes, no and status further divided on two options useable and unusable, appropriateness and inappropriateness.

Observation checklist of educational facilities was used to analyze the situation. The structured observation checklist was rating the availability and quality of the following facilities:

1. School building condition

2. Academic facilities

3. Proper classroom and furniture are present as per students' strength

4. School library

5. Laboratory

6. Computer lab 
7. School environment

8. And useful and helpful teaching and learning materials and facilities.

\subsection{Validity of the Instrument}

The instrument was getting validated through repeated consultation with the supervisor and from the two experts. Both of the experts validated these with few minor amendments and advised to draw the questionnaire and observation checklist in 8 parts.

\subsection{Reliability of the Instrument}

To improve the achievement test, twenty heads and sixty teachers of secondary schools were selected from Bahawalnagar for research. Cronbach Alpha was calculated to check the reliability of questionnaire and observation checklist. The reliability of test 60 statements of questionnaire were calculated through Cronbach Alpha which was 0.88 and observation checklist was based on 30 statements were calculated through Cronbach Alpha which was 0.85 .

\subsection{Collection of data}

The researcher visited the respective places for data collection of sample. The researcher distribute questionnaire among the head teachers and SSTs to get responses. Observations were adopted in the research to assemble the necessary highlights regarding the current situation of the study area. Observation finding was systematically recorded in the checklist. The observation was taken place in the secondary schools of tehsil Bahawalnagar.

\subsection{Data analysis}

After data collection, the data was organized, tabulated, analyzed and interpret. Data was analyzed using descriptive statistics including percentage and frequency to examine the appropriateness of educational facilities. Descriptive statistics mean, SD were calculated. Data were analyzed by utilizing SPSS.

\section{Results}

Data analysis and the interpretation of results that based on study objectives have been described. This chapter carried the demographic information of respondents and the interpretation of data collected from the respondents. The research was conducted to examine and analyze the educational facilities in secondary schools of district Bahawalnagar. The data collected from teachers and head teachers using questionnaire. Data was collected by personal visits. After data collection, it was organized, tabulated, analyzed and interpreted by computer software Statistical Package for Social Science (SPSS). Percentage was used for the statistical analysis of data. In order to describe the result, statistics gathered that included mean and standard deviation.

\subsection{Response Rate of Return Respondents}

The researcher was collected quantitative data. For the quantitative data collection, the researcher dispensed a questionnaire to the 135 respondents including head teachers and teachers SSTs of secondary school in district Bahawalnagar. Respondents were categorized in gender, designation, area and tehsil. It reveals that all questionnaires were filled up with interest and were returned. All questionnaires were filled according to the asked statements.

\subsection{Demographic Information of Respondents}

The demographic background includes gender, designation area and tehsil. There were 45 secondary schools of district Bahawalnagar. There were 16 girls' secondary schools and 29 boys' secondary schools in district Bahawalnagar. In which 48 female respondents and 87 male respondents of secondary schools in district Bahawalnagar. It was explained that total 135 respondents, there were 45 head teachers and 90 SSTs.

\subsection{Survey Instrument}

The survey instrument was developed for collecting data from the head and teachers. The survey instrument was designed by the help of study objectives. The questionnaire was consisted upon 35 statements, all with five options of responses i.e., strongly agree, and Agree, Neutral, Disagree, Strongly Disagree. All the statements are being discussed here. 
Table 1: Responses of the respondents about the availability of educational facilities in secondary schools.

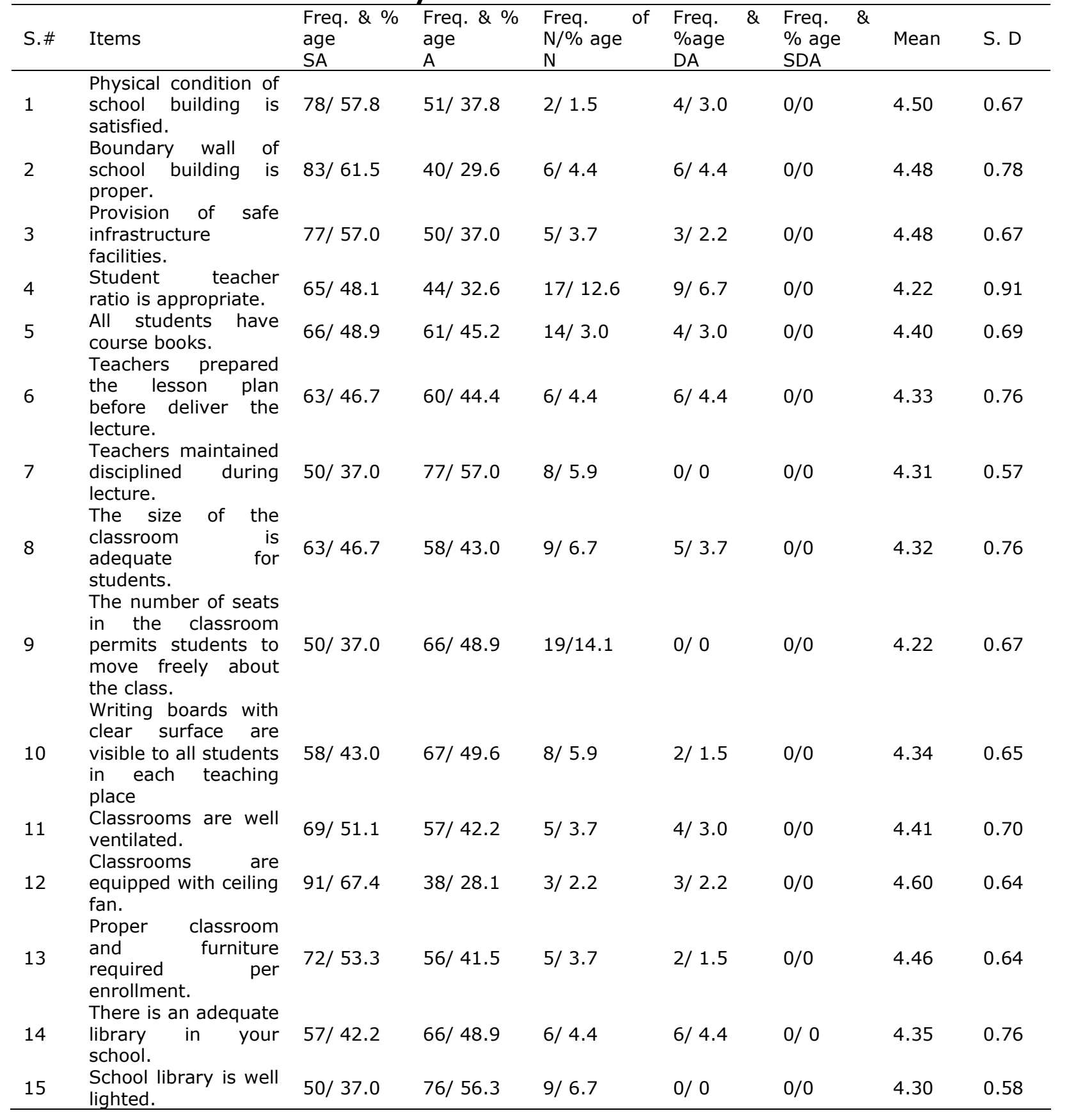

In table 1 , the overall results obtained from data of questionnaire showed it clearly that the secondary schools of district Bahawalnagar availability of educational facilities were present. Majority of respondents were strongly agreed with availability of educational facilities. From the result, school building such as physical condition of school building, proper boundary wall, infrastructure facilities, course books, size of classroom, classroom well ventilated, ceiling fans, furniture required per enrollment, science and computer laboratory facilities are mostly available, mostly respondents are satisfied thus result in the high ranking $87 \%$ respondents were agreed. On the other side separate reading room of library, lack of parents involvements, proper shelving and storage of facilities in laboratory, Over Head Projector, bus facilities, computer or electronic media are not located in secure places, at least one computer per group of two students, students cannot freely use Wi-Fi network mostly respondents disagree all these facilities.

\subsection{Checklist}

The provisions of the educational facilities in the school were evaluated by observations. The checklist was designed by the help of the objectives of the study. The 
checklist was consisted upon 30 statements. Observation checklist will be consisted on three options yes, no and status further divided on two options useable and unusable, appropriateness and inappropriateness.

Table 2: Educational facilities in secondary schools were evaluated by observation checklist

\begin{tabular}{|c|c|c|c|c|c|c|c|}
\hline S\# & Item & $\begin{array}{l}\text { Freq. } \\
\text { YES }\end{array}$ & $\%$ Age & $\begin{array}{l}\text { Freq. } \\
\text { No }\end{array}$ & $\%$ Age & Mean & S. D \\
\hline 1 & $\begin{array}{l}\text { The building is free from hazards } \\
\text { from road traffic. }\end{array}$ & 31 & 71.1 & 13 & 28.9 & 0.71 & 0.45 \\
\hline 2 & $\begin{array}{l}\text { The building is free of all types of } \\
\text { environmental pollution (like } \\
\text { smoke, dust, odors, etc.). }\end{array}$ & 36 & 80.0 & 9 & 20.0 & 0.80 & 0.40 \\
\hline 3 & $\begin{array}{l}\text { The building is calm and peaceful } \\
\text { for the teaching-learning process. }\end{array}$ & 41 & 91.1 & 4 & 8.9 & 0.91 & 0.28 \\
\hline 4 & $\begin{array}{l}\text { Maintenance and cleaning materials } \\
\text { are properly stored. }\end{array}$ & 36 & 80.0 & 9 & 20.0 & 0.80 & 0.40 \\
\hline 5 & $\begin{array}{l}\text { Lesson plan prepared by teachers } \\
\text { before deliver the lesson. }\end{array}$ & 41 & 91.1 & 4 & 8.9 & 0.91 & 0.28 \\
\hline 6 & Teachers used audio visual aids. & 41 & 91.1 & 4 & 8.9 & 0.91 & 0.28 \\
\hline 7 & All students have course books. & 31 & 68.9 & 14 & 31.1 & 0.68 & 0.46 \\
\hline 8 & $\begin{array}{l}\text { Proper classroom and furniture } \\
\text { required per enrollment. }\end{array}$ & 28 & 62.2 & 17 & 37.8 & 0.62 & 0.49 \\
\hline 9 & $\begin{array}{l}\text { Classes are overcrowded hampering } \\
\text { proper attention }\end{array}$ & 31 & 68.9 & 14 & 31.1 & 0.68 & 0.46 \\
\hline 10 & $\begin{array}{l}\text { Furniture is properly maintained for } \\
\text { students. }\end{array}$ & 32 & 71.1 & 13 & 28.9 & 0.71 & 0.45 \\
\hline 11 & $\begin{array}{l}\text { There is proper classroom of } \\
\text { seating arrangement. }\end{array}$ & 40 & 88.9 & 5 & 11.1 & 0.88 & 0.31 \\
\hline 12 & $\begin{array}{l}\text { There is provision of classroom } \\
\text { furniture for students. }\end{array}$ & 36 & 80.0 & 9 & 20.0 & 0.80 & 0.40 \\
\hline 13 & Classrooms are well ventilated. & 31 & 68.9 & 14 & 31.1 & 0.68 & 0.46 \\
\hline 14 & $\begin{array}{l}\text { Equipment of science laboratory } \\
\text { fulfills the need of the students. }\end{array}$ & 31 & 68.9 & 14 & 31.1 & 0.68 & 0.46 \\
\hline 15 & $\begin{array}{l}\text { Chemicals and lab equipment are } \\
\text { stored safely when not in use. }\end{array}$ & 36 & 80.0 & 9 & 20.0 & 0.80 & 0.40 \\
\hline
\end{tabular}

In table 2, on the other hand, when the data from questionnaire and observation checklist were gathered and matched for cross checking, some notable findings were revealed that the school building components that were provided as well as useable and appropriateness such as school building condition maximum number of school's condition is better of school building facilities. Cleaning materials were properly stored, safe and proper areas for parking factors were good.

\subsection{Summary of Findings}

The overall results obtained from data of questionnaire and observation checklist showed it clearly that the secondary schools of district Bahawalnagar availability of educational facilities were present. Majority of respondents were strongly agreed with availability of educational facilities. From the result, school building such as physical condition of school building, proper boundary wall, infrastructure facilities are satisfied thus result in the high ranking $87 \%$ respondents were agreed. Academic facilities components such as student teacher ratio, all students have course books, teacher prepared the lesson plan and maintained discipline during lesson all these facilities were good and $(89 \%)$ respondents were strongly agreed. Mostly heads and teachers were strongly agree with classrooms and furniture, size of classrooms, seating arrangements, blackboard/whiteboard provided and visible to all students, proper classrooms and furniture require per enrollment, classrooms are well ventilated and equipped with ceiling fans (90\%) respondents were strongly agreed classrooms and furniture were available in secondary schools. Adequate library and library well lighted facilities were present and head and teachers were satisfying and strongly agree with all these facilities in which (85\%) facilities were available. But on the other hand, when the data from questionnaire and observation checklist were gathered and matched for cross checking, some notable findings were revealed that the school building components that were provided as well as useable and appropriateness such as school building condition maximum number of school's condition is better of school building facilities. Cleaning materials were properly stored, Student strength according to teachers, teacher used audio visual aids, proper classroom and 
furniture required per enrollment, classrooms were well lighted, Lesson plan prepared, all students have course books, proper attention on classes, furniture available, seating arrangement, equipment of science laboratory fulfils the need of the students and chemicals and lab equipment are stored safely when not in use all these factors were available and useable. Overall observation checklist percentage are physical infrastructure and school building $(82 \%)$, teaching learning material and academic facilities $(85 \%)$, classroom and furniture $(87 \%)$, school library $(78 \%)$, science laboratory $(68 \%)$.

\section{Discussion}

From the findings, school building such as physical condition of school building, proper boundary wall, infrastructure and instructional facilities were providing satisfied results. But these facilities need to be maintained and more improvement to create a pleasant environment for the school society. In addition, the facilities that were provided in the school area must obey the high level safety of school community. Academic facilities components such as student teacher ratio, all students have course books, used audio visual aids and maintained discipline during lesson all these facilities were good. Audio- Visual aids are supportive in teaching as they create interest and motivated the students to learn. It was noted that students learning power increased by observing, watching as compared to traditional teacher's lessons. Classrooms and furniture factors such as size of classrooms, seating arrangements, students freely move, properly maintained, blackboard/whiteboard provided and visible to all students, duster and chalks were present near blackboard/whiteboard, classrooms ventilated, ceiling fans, provision of classrooms furniture for students, proper classrooms and furniture require per enrollment, school library elements such as adequate library, students receive books and library well lighted all these facilities were present. From the site observations, the school components that were provided as well as useable and appropriateness such as school building condition maximum number of school's condition is better of school building facilities. Building was free from hazards, environmental pollution, calm and peaceful environments, proper boundary wall, safe and proper area for parking all these components of checklist were satisfactory. Maintenance and cleaning materials were properly stored, safe and proper area for parking factors were good. Student strength according to teachers, teacher used audio visual aids, proper classroom and furniture required per enrollment, classrooms were well lighted, equipment of science laboratory and chemicals safely stored all these elements were satisfied. Lesson plan prepared, all students have course books, proper attention on classes, furniture available and seating arrangement all these factors were available and useable.

\section{Conclusion}

This study concluded that appropriateness of physical infrastructure in secondary schools building condition was analyzed, a satisfactory result was found overall structural building conditions at secondary schools. Majority respondents were strongly agreed from facilities were available in secondary schools. The results drawn from the data were that majority of the respondents were agree with academic achievement, student teacher ratio was appropriate, all students have course books, teacher used audio visual aids during deliver lecture. Classrooms and furniture were analyzed that seating arrangement of classrooms, size of classrooms, chalk duster, blackboard, classrooms were well ventilated, classrooms are equipped with ceiling fan and proper classroom and furniture required per enrollment all these facilities were satisfactory. The study was analyzed that appropriateness of teaching learning material and library in secondary schools. Majority of respondents were strongly agreed with availability of teaching learning material. Head and teachers were satisfying with all these facilities but appropriateness of school library in secondary schools in which provision of Over Head projector and LCD projector in the schools is not present and percentage in the lowest ranking. This research was concluded that School environment majority facilities are exist and majority of respondents were strongly agreed. Science laboratory show that greater part of educational facilities is available in the secondary school level. All heads and teachers (SSTs) were strongly agreed for availability of science laboratory facilities. The above conclusions and results came out after this research. The researchers made some workable recommendations which are explained as under:

- In secondary schools it was investigated that LCD projectors, at least one computer per group of two students in the laboratory may be available. 
- It was founded that transport facility was not available both for students and teachers. Therefore, it is recommended that transport facility may be provided for students and teachers.

- It was revealed in this study that there were not any specially designed rooms for library, scientific equipment and educational technologies. Therefore it is recommended that specially designed rooms may be built for library, scientific equipment and educational technologies.

\section{References}

Andrabi, T., Khan, S., Khan, Y., \& Naseer, M. F. (2016). Learning in public schools (Working Paper No. 12/0390). London, UK: International Growth Centre

Asaolu, A.G., (2003) Predictive validity of JSC mathematics examination on the performance of students in science subjects in Ekiti State secondary schools. Unpublished M.Ed. Thesis, Faculty of Education, University of Ado-Ekiti; Nigeria, 50-76.

Bruce, T. (2006). Early Childhood Education: A guide for students. London: SAGE Publications.

Davis, R. A. (2015). A cognitive-behavioral model of pathological Internet use. Computers in Human Behavior, 17(2), 187-195. https://doi.org/10.1016/S0747-5632(00)00041-8

Ndungu, B. W., Allan, G., \& Bomett, E. J. (2015). Influence of Monitoring and Evaluation by Principals on Effective Teaching and Learning in Public Secondary Schools in Githunguri District. Journal of Education and Practice, 6(9), 10-17.

Government of Pakistan (2009). National Education Policy. Islamabad: Ministry of Education.

Khan, A. M., \& Mirza, M. S. (2012). Opinions and perceptions of head teachers (HTs) towards devolution in education in Pakistan. Journal of Elementary Education, 22(2), 13-32.

Perera, W.J. (2014). Changing School from within: a Management Intervention for Improving School Functioning in Sri Lanka. International Institute of Education Planning.

Schneider, M. (2002). Do school facilities affect academic outcomes? National Clearinghouse for Educational Facilities. $\quad$ Retrieved from http://www.edfacilities.org/pubs/outcomes.pdf. On 20-04-05

School Education Department. (2018). School College Systems by High School Government of Punjab. https://schools.punjab.gov.pk/>policy

Shami, P. A., \& Hussain, K. S. (2005). Basic education in Pakistan: Academy of Educational Planning and Management, Ministry of Education.

Tutkun, O. (2011). Internet access, use and sharing levels among students during the teaching learning process. The Turkish Online Journal of Educational Technology, 10(3), 152-160.

Vandiver, B. (2011). The impact of school facilities on the learning environment: Capella University.

Weems, D. M., \& Rogers, C. H. (2015). Are U.S. Teachers making the grade? A proposed framework for teacher evaluation and professional growth. Management Education, 24(1), 19-24.

World Bank, 2007. How to build M\&E system to support better government. World Bank. Washington

Young, E., Green, H. A., Roehrich-Patrick, L., Joseph, L., \& Gibson, T. (2003). Do K-12 School Facilities Affect Education Outcomes? Staff Information Report. 